\title{
CYCLIN D1, RET AND P27 EXPRESSION IN PAPILLARY THYROID MICROCARCINOMA
}

\author{
Ana Barić ${ }^{1}$, Vinko Marković ${ }^{1}$, Davor Eterović ${ }^{1}$, Vladimir Bedeković $^{2}$, Mirko Kontić3, \\ Ljubica Juretić Kuščić ${ }^{1}$, Valdi Pešutić Pisac ${ }^{4}$ and Ante Punda ${ }^{1}$
}

\author{
${ }^{1}$ Clinical Department of Nuclear Medicine, Split University Hospital Center, Split; \\ ${ }^{2}$ Clinical Department of ENT, Sestre milosrdnice University Hospital Center, Zagreb; \\ ${ }^{3}$ Clinical Department of ENT, ${ }^{4} \mathrm{Clinical}$ Department of Pathology, Forensic Medicine and Cytology, \\ Split University Hospital Center, Split, Croatia
}

\begin{abstract}
SUMMARY - The aim of the study was to determine the influence of RET, p27 and cyclin D1 on regional lymph node metastases in papillary microcarcinoma. The analysis included 70 patients with papillary thyroid microcarcinoma that underwent surgery at Split University Hospital Center between 1999 and 2001. Immunohistochemistry was performed on formalin-fixed, paraffin-embedded tissue by the RET, p27 and cyclin D1 antibodies. Quantification was based on the intensity and distribution of nuclear staining, dividing tumors into those that showed expression (expressors) and those that showed no expression (non-expressors). Univariate analysis using $\chi^{2}$-test and Fisher exact test was performed with the level of statistical significance set at $\mathrm{p}<0.05$. There was no statistically significant difference in the incidence of metastases according to the expression or non-expression of RET mutation ( $\chi^{2}$-test: $\mathrm{p}=0.459$; Fisher exact test: $\left.\mathrm{p}=0.672\right)$. Among 25 cases with cyclin D1 expression, 6 had metastases, whereas only 2 of 45 cases with no cyclin D expression had metastases $\left(\chi^{2}\right.$-test: $\mathrm{p}=0.014$; Fisher exact test: $\mathrm{p}=0.021$ ), indicating that the expression of cyclin D1 is not crucial for the development of metastases in lymph nodes. In contrast, analysis of p27 expression showed it to be significantly associated with lymph node metastasis because 3 of 45 patients with p27 expression had metastases, indicating a statistically significant correlation between p27 expression and lymph node metastases ( $\chi^{2}$-test: $p=0.093$; Fisher exact test: $\left.p=0.124\right)$. This study confirmed the importance of the evaluation of RET, p27 and cyclin D1 expression and demonstrated the validity of their application in the assessment of microcarcinoma behavior.
\end{abstract}

Key words: Thyroid cancer, papillary [Supplementary Concept]; Thyroid carcinoma, anaplastic; Cyclin D1; Cyclin-dependent kinase inbibitor 2 27; RET protein, human

\section{Introduction}

"Papillary carcinoma in a size of one centimeter or less, composed of papillae or follicles with typical nuclei" is the definition that Hazard set in 1960 for papillary microcarcinoma, and it has been accepted by the World Health Organization ${ }^{1,2}$. Some authors have

Correspondence to: Ana Baric, $M D$, Clinical Department of $\mathrm{Nu}-$ clear Medicine, Split University Hospital Center, Spinčićeva 1, HR-21000 Split, Croatia

E-mail: ana.baaric@gmail.com

Received February 10, 2016, accepted September 12, 2016 recently tended to define this entity as a separate category, not as a subtype of papillary carcinoma ${ }^{3}$. Numerous terms have been used for this entity, describing its clinical presentation and histologic features, e.g., occult sclerosing carcinoma, nonencapsulated sclerosing tumor, occult papillary tumor, and small papillary carcinoma ${ }^{4-6}$. The most commonly used term is papillary microcarcinoma, while other terms cannot precisely describe its behavior. Clinicians often use the term occult cancer because cancer is present but has no clinical symptoms and is often revealed as an incidental finding ${ }^{4}$. Therefore, the term incidental cancer is 
increasingly used, as it is mostly presented as an incidental clinical or autopsy finding ${ }^{3}$. These frequent incidental autopsy findings, where death was caused by some other disease, have led some researchers to consider papillary thyroid tumor smaller than 5 millimeters as a normal finding ${ }^{7}$. Fink et al. found incidental papillary thyroid cancer in one-third of autopsy cases and in $24 \%$ of thyroidectomies performed for other thyroid diseases ${ }^{5}$. However, there is some evidence that even those cancers smaller than $5 \mathrm{~mm}$ can metastasize to lymph nodes, and very rarely to distant organs ${ }^{8-10}$.

In this study, the term metastases or metastatic cancer refers only to regional lymph node metastases. However, some authors have proposed changing the term papillary microcarcinoma into papillary microtumor, with clear exception of those that occur in patients younger than 19 years and if lymph node metastases are present ${ }^{11}$.

In this study, we investigated expression of RET, p27 and cyclin D1 in papillary thyroid microcarcinoma with or without regional lymph node metastases, to reveal differences in biological profile due to clinical behavior.

Cyclin D1 gene, located on chromosome 11q23, is a positive regulator of the cell cycle, allowing for cell cycle progression from $\mathrm{G} 1$ to $\mathrm{S}$ phase ${ }^{12}$. Tumor suppressor gene p27 is located on chromosome $12 \mathrm{p} 13$. It encodes the CDK inhibiting nuclear protein and inhibits the formation of cyclinD1/cdk complexes during G0 and early G1 phases of the cell cycle ${ }^{12}$. Cyclin D1 overexpression and p27 underexpression were found in a variety of tumors and were associated with increased tumor aggressiveness, incidence of lymph node metastases, and poorer prognosis ${ }^{13}$.

RET proto-oncogene is located on the long arm of chromosome 10. In the pathogenesis of papillary thyroid cancer, activation of RET includes rearrangement or gene redistribution ${ }^{14}$.

The average representation of RET mutations in sporadic papillary cancers in adults is $20 \%-30 \%$; it is increased in childhood and young age tumors to up to $45 \%-50 \%$, and is highest in cancers in people having been exposed to accidental or therapeutic radiation, amounting to $50 \%-80 \%{ }^{15}$.

\section{Materials and Methods}

Histologic and immunohistologic analysis included 70 patients with papillary thyroid microcarcinoma that underwent surgery at Split University Hospital Center between 1999 and 2001.

Formalin-fixed, paraffin-embedded, $3-\mu \mathrm{m}$ thick tissue sections were deparaffinized in toluene and rehydrated through graded alcohols to water. Endogenous peroxidase activity was blocked by $0.5 \%$ hydrogen peroxide. Antigen retrieval was performed in $10 \mathrm{mmol} / \mathrm{L}$ citrate buffer $(\mathrm{pH}$ 6.0) inside a microwave pressure cooker. Slides were immediately placed into a tap water bath. Sections were washed in Tris buffered saline (TBS) for $1 \times 5$ minutes, placed in diluted normal serum for 10 minutes, and finally incubated.

For all three primary monoclonal antibodies, the same manufacturer (Novocastra, Newcastle Upon Tyne, United Kingdom) was selected: monoclonal antibody for RET oncoprotein clone 3F8 P (HIER); p27 protein monoclonal antibody clone 1B4 P (HIER) W; and cyclin D1 monoclonal antibody clone P2D11F11 P (HIER/Enzyme) W.

Immunohistochemical staining was performed according to the manufacturer's instructions (Novocastra, Vision Bio Systems (Europe), Newcastle Upon Tyne, United Kingdom).

The intensity of cyclin D1 expression refers only to nuclear staining of tumor cells: G0 - total absence; G1 - faint nuclear staining; G2 - moderate nuclear staining; and G3 - intense nuclear staining. Tumors with grades 0-1 were defined as non-expressors. Distribution was also observed and graded as follows: G1 - focal, less than $10 \%$ of tumor cells; G2 - 10\%-50\% of tumor cells; and G3 - diffuse, $>50 \%$ of tumor cells.

On statistical analysis, tumors were divided into those that showed expression (expressors) and those that showed no expression (non-expressors). Expressors had moderate or intense nuclear staining with diffuse distribution (Fig. 1), while non-expressors had complete absence of staining. If there were tumors that showed faint or focal staining in $<10 \%$ of tumor cells, they were also classified as non-expressors ${ }^{16}$.

The expression of p27 was also analyzed according to the intensity of nuclear staining. The intensity is graded as G0-G4: G0 - total absence of staining; G1 - faint nuclear staining; G2 - moderate nuclear staining; G3 - intense nuclear staining; and G4 - staining as strong as in normal thyroid tissue (Fig. 2). Tumors with grades 0-1 were defined as non-expressors.

Both staining methods have common control, i.e. normal thyroid tissue is positive control for p27 and 


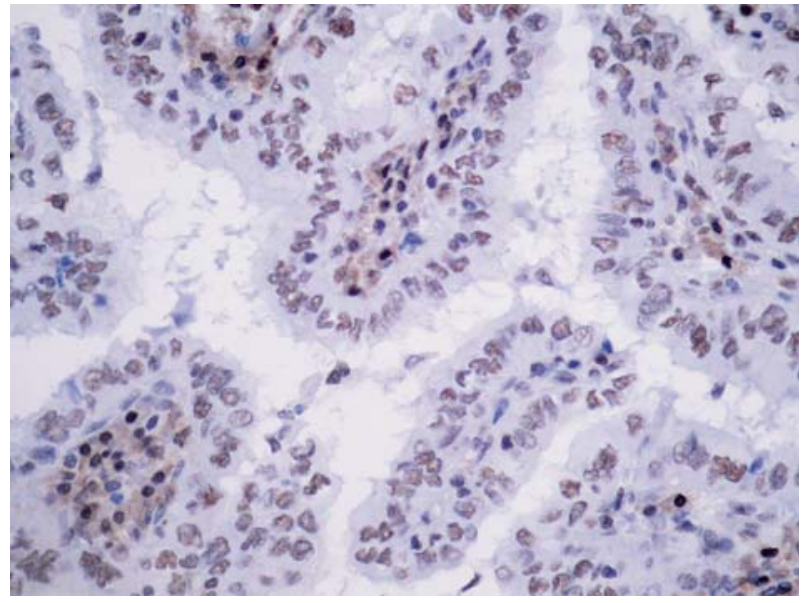

Fig. 1. Expressor: G2 - moderate, easily visible nuclear staining; G3 - diffuse (cyclin D1, magnification 40x).

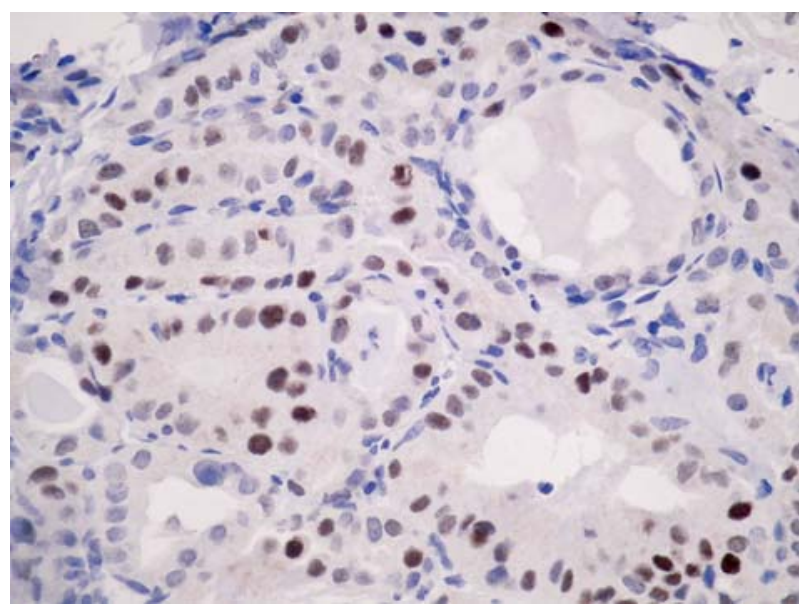

Fig. 2. Expressor: G3 - strong nuclear coloration (p27, magnification 40x).

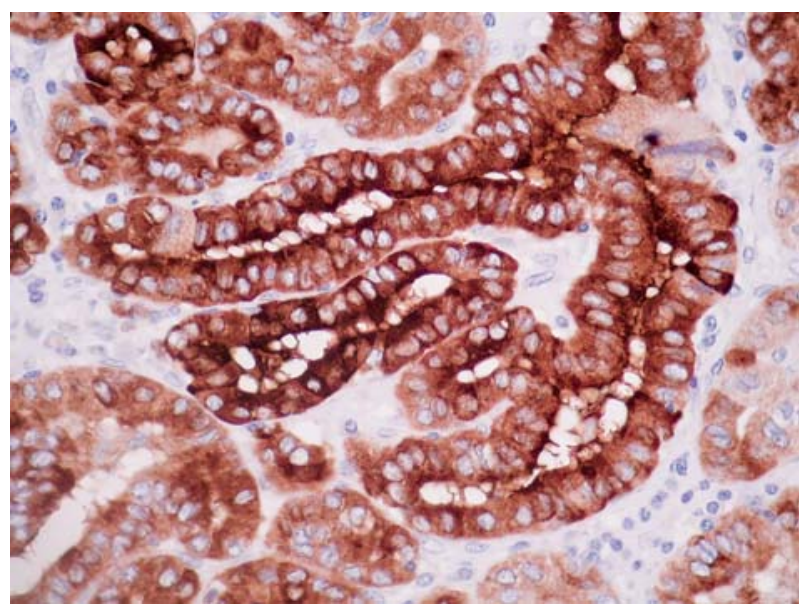

Fig. 3. Positive RET, cytoplasmic staining (RET, magnification 40x). negative control for cyclin D1. Positive control for cyclin D1, but negative for $\mathrm{p} 27$ is mantle cell lymphoma ${ }^{17}$.

The presence of RET/PTC was determined by diffuse cytoplasmic staining on normal measuring scale (Fig. 3). The absence of staining is the absence of the investigated mutation.

Ganglion cells of the small intestine were positive control ${ }^{18}$.

\section{Statistical analysis}

RET, cyclin D1 and p27 expression was included in the univariate analysis using $\chi^{2}$-test to determine predictors of lymph node metastases in papillary thyroid microcarcinoma. The level of statistical significance was set at $\mathrm{p}<0.05$. We used Statistical Package for the Social Sciences, version 13.0 for Windows (SPSS Inc., Chicago, IL, USA).

\section{Results}

In the series of 70 microcarcinomas, expression of RET mutation was present in 16 (22.9\%) cases. There was no statistically significant difference in the incidence of metastases according to expression or nonexpression of RET mutation (Table 1).

Cyclin D1 was expressed in 25 (35.7\%) of $70 \mathrm{pa}^{-}$ tients. Metastases were present in 6 of 25 cases with cyclin D1 expression and in only 2 of 45 cases with no cyclin $\mathrm{D}$ expression. In this series, it was quite difficult to assess statistically significant influence $\left(\chi^{2}\right.$-test: $\mathrm{p}=0.014$; Fisher exact test $\mathrm{p}=0.021$ ) of cyclin D1 ex-

Table 1. Incidence of RET mutation in papillary microcarcinomas and relationship between RET mutation expression and lymph node metastases

\begin{tabular}{|l|c|c|c|}
\hline RET & $\begin{array}{c}\text { Lymph node } \\
\text { metastases } \\
\text { present }\end{array}$ & $\begin{array}{c}\text { No lymph } \\
\text { node } \\
\text { metastases }\end{array}$ & $\begin{array}{c}\text { Number } \\
(\%)\end{array}$ \\
\hline Non- & 7 & 47 & 54 \\
expressor & $87.5 \%$ & $75.8 \%$ & $77.1 \%$ \\
& $13.0 \%$ & $87.0 \%$ & $100 \%$ \\
\hline Expressor & 1 & 15 & 16 \\
& $12.5 \%$ & $24.2 \%$ & $22.9 \%$ \\
\hline Total & $6.3 \%$ & $93.8 \%$ & $100 \%$ \\
& 8 & 62 & 70 \\
& $100 \%$ & $100 \%$ & $100 \%$ \\
\hline
\end{tabular}

$\chi^{2}$-test: $\mathrm{p}=0.459$; Fisher exact test: $\mathrm{p}=0.672$ 
Table 2. Cyclin D1 expression in papillary microcarcinomas and relationship between cyclin D1 expression and lymph node metastases

\begin{tabular}{|l|c|c|c|}
\hline Cyclin D1 & $\begin{array}{c}\text { Lymph node } \\
\text { metastases } \\
\text { present }\end{array}$ & $\begin{array}{c}\text { No lymph } \\
\text { node } \\
\text { metastases }\end{array}$ & $\begin{array}{c}\text { Number } \\
(\%)\end{array}$ \\
\hline Non- & 2 & 43 & 45 \\
expressor & $25 \%$ & $69.4 \%$ & $64.3 \%$ \\
\hline Expressor & $4.4 \%$ & $95.6 \%$ & $100 \%$ \\
& $75 \%$ & 19 & 25 \\
& $24 \%$ & $76 \%$ & $35.7 \%$ \\
& 8 & 62 & $100 \%$ \\
\hline Total & $100 \%$ & $100 \%$ & $100 \%$ \\
& $11.4 \%$ & $88.6 \%$ & $100 \%$ \\
\hline
\end{tabular}

$\chi^{2}$-test: $p=0.014$; Fisher exact test: $p=0.021$

Table 3. Expression of 27 in papillary microcarcinomas and correlation between $p 27$ expresssion and lymph node metastases

\begin{tabular}{|l|c|c|c|}
\hline p27 & $\begin{array}{c}\text { Lymph node } \\
\text { metastases } \\
\text { present }\end{array}$ & $\begin{array}{c}\text { No lymph } \\
\text { node } \\
\text { metastases }\end{array}$ & $\begin{array}{c}\text { Number } \\
\%\end{array}$ \\
\hline Non- & 5 & 20 & 25 \\
expressor & $62.5 \%$ & $32.3 \%$ & $35.7 \%$ \\
& $20 \%$ & $80 \%$ & $100 \%$ \\
\hline Expressor & 3 & 42 & 45 \\
& $37.5 \%$ & $67.7 \%$ & $64.3 \%$ \\
& $6.7 \%$ & $93.3 \%$ & $100 \%$ \\
\hline Total & 8 & 62 & 70 \\
& $100 \%$ & $100 \%$ & $100 \%$ \\
& $11.4 \%$ & $88.6 \%$ & $100 \%$ \\
\hline
\end{tabular}

$\chi^{2}$-test: $p=0.093$; Fisher exact test: $p=0.124$

pression because there were only 2 metastatic cancers in the group without cyclin D expression (Table 2).

In the series of 70 microcarcinomas, $\mathrm{p} 27$ expression was present in 45 (64.3\%) cases. In the group with p27 expression only 3 of them had metastases, indicating a statistically significant correlation between p27 expression and metastatic behavior $\left(\chi^{2}\right.$-test: $\mathrm{p}=0.093$; Fisher exact test $\mathrm{p}=0.124)$ (Table 3$)$.

\section{Discussion}

Papillary thyroid microcarcinoma is an entity that has been very often a subject of debate because the common therapeutic protocol requires total thyroidectomy, whereas many studies have shown it to have a good prognosis, suggesting that cancer smaller than 5 $\mathrm{mm}$ should be considered as a normal finding ${ }^{7}$. This extremely favorable prognosis has led to proposals to change the term cancer and replace it with the term tumor-papillary microtumor, which is more acceptable for patients ${ }^{11}$.

Lymph node metastases are rare, and metastases to distant organs are considered to be case reports $8,10,11$. Those rare cases have prompted researchers to investigate difference in the biological profile of these metastatic rarities and to find out how to recognize them in order to provide better therapeutic choice and follow up. Examining the RET mutation in papillary carcinoma, Sugg et al. identified it mainly in occult microcarcinomas ${ }^{19}$. In their studies, Soares et al. and Tallini et al. showed the RET mutation to be more common in small, slow growing tumors, and to potentially serve as a favorable prognostic marker ${ }^{20,21}$.

In our study, 70 patients were selected according to the criteria for microcarcinomas ${ }^{3}$. We studied the prevalence of RET mutation, and found it to be present in $22.9 \%$ of cases (Table 1). This result is not in accordance with those reported by Sugg et al. ${ }^{19}$, but complies with the average presence of RET mutation in sporadic cancers ${ }^{15,22-24}$. Lymph node metastases were present in 8 patients and no statistically significant correlation with RET mutation was found (Table 1).

The appearance of metastases in microcarcinomas led Khoo et al. to evaluate cyclin D1 expression. They found cyclin D1 expression to be increased in $90 \%$ of metastatic cancers and conclude that it is necessary to form subgroups of these microcarcinomas at the molecular level ${ }^{25}$. In our study, we recorded cyclin D1 expression in $25(35.7 \%)$ of 70 microcarcinomas, whereas in the group with lymph node metastases cyclin D1 expression was present in $6(75 \%)$ of 8 cases $(p=0.014)$ (Table 2). This percentage was lower than that reported by Khoo et al. ${ }^{25}$, but is still significant, especially in combination with p27 expression.

In our study, $69.4 \%$ of microcarcinomas without lymph node metastases did not express cyclin D1 (Table 2), which is consistent with the study by Kovacs et al., who found the majority of microcarcinomas identified as incidental autopsy finding to have low expression of cyclin $\mathrm{D} 1^{26}$. 
We also investigated p27 expression in this group of microcarcinomas and found it to be expressed in $63.4 \%$ of cases, confirming the previously described finding that lymph node metastases showed a statistically significant correlation with cyclin D1 expression and p27 non-expression ( $\mathrm{p}=0.093$ ) (Table 3). Similarly, Khoo et al. report on a decreased level of p27 expression in papillary microcarcinomas with lymph node metastases as compared with those without lymph node metastases ${ }^{27}$.

These results confirmed the importance of evaluating $\mathrm{p} 27$, cyclin D1 and RET expression, suggesting their potential usefulness in the evaluation of microcarcinoma behavior.

\section{References}

1. Hazard JB. Small papillary carcinoma of the thyroid. A study with special reference to so-called nonencapsulated sclerosing tumor. Lab Invest. 1960;9:86-97.

2. Lantsov DS. Thyroid microcarcinoma. Arkh Patol. 2006;68 (4):54-7.

3. DeLellis RA, Lloyd RV, Heitz PU, Eng C. Tumors of the thyroid and parathyroid. In: DeLellis RA, Lloyd RV, Heitz PU, Eng C, editors. Pathology and Genetics of Tumours of Endocrine Organs. Lyon: IARC; 2004. p. 50-66.

4. Rosai J, Carcangiu ML, DeLellis RA. Papillary carcinoma. In: Rosai J, Carcangiu ML, DeLellis RA, editors. Tumors of the Thyroid Gland. Atlas of Tumor Pathology. Third Series Fascicle 5. Washington DC, 1990. AFIP 65-144.

5. Fink A, Tomlinson G, Freeman JL, Rosen IB, Asa SL. Occult micropapillary carcinoma associated with benign follicular thyroid disease and unrelated thyroid neoplasms. Mod Pathol. 1996;9:816-20.

6. Yamamoto Y, Maeda T, Izumi K, Otsuka H. Occult papillary carcinoma of the thyroid. A study of 408 autopsy cases. Cancer. 1990;65(5):1173-9.

7. Harach HR, Franssila KO, Wasenius VM. Occult papillary carcinoma of the thyroid. A "normal“ finding in Finland. A systematic autopsy study. Cancer. 1985;56(3):531-8.

8. Chow SM, Law SC, Chan JK, Au SK, Yau S, Lau WH. Papillary microcarcinoma of the thyroid - prognostic significance of lymph node metastasis and multifocality. Cancer. 2003;98 (1):31-40, https://dx.doi.org/10.1002/cncr.11442

9. Allo MD, Christianson W, Koivunen D. Not all „occult“ papillary carcinomas are „minimal“. Surgery. 1988;104(6):971-6.

10. Lang W, Borrusch H, Bauer L. Occult carcinomas of the thyroid. Evaluation of 1,020 sequential autopsies. Am J Clin Pathol. 1988;90(1):72-6.

11. Rosai J, LiVolsi VA, Sobrinho-Simoes M, Williams ED. Renaming papillary microcarcinoma of the thyroid gland: the Porto proposal. Int J Surg Pathol. 2003;11:249-51.
12. Wang S, Wuu J, Savas L, Patwardhan N, Khan A. The role of cell cycle regulatory proteins, cyclin D1, cyclin E, and p27 in thyroid carcinogenesis. Hum Pathol. 1998;29:1304- 9.

13. Kim DH, Lee HI, Nam ES, Shin HS, Sohn JH, Park CH, et al. Reduced expression of the cell-cycle inhibitor p27Kip1 is associated with progression and lymph node metastasis of gastric carcinoma. Histopathology. 2000;36:245-51.

14. Fischer AH, Bond JA, Taysavang P, Battles OE, WynfordThomas D. Papillary thyroid carcinoma oncogene (RET/PTC) alters the nuclear envelope and chromatin structure. Am J Pathol. 1998 Nov;153(5):1443-50, https://dx.doi.org/10.1016/ S0002-9440(10)65731-8

15. Sadetzki S, Calderon-Margalit R, Modan B, Srivastava S, Tuttle RM. Ret/PTC activation in benign and malignant thyroid tumors arising in a population exposed to low-dose external-beam irradiation in childhood. J Clin Endocrinol Metab. 2004 May;89(5):2281-9, https://dx.doi.org/10.1210/jc.2003-030481

16. Hawk WA, Hazard JB. The many appearances of papillary carcinoma of the thyroid. Cleve Clin Q. 1976;43(4):207-15.

17. Carcangiu ML, Zampi G, Rosai J. Papillary thyroid carcinoma: a study of its many morphologic expressions and clinical correlates. Pathol Annu. 1985;20:1-44.

18. Shin E, Chung WY, Yang WI, Park CS, Hong SW. RET/PTC and CK19 expression in papillary thyroid carcinoma and its clinicopathological correlation. J Korean Med Sci. 2005;20: 98-104, https://dx.doi.org/10.3346/jkms.2005.20.1.98

19. Sugg SL, Zheng L, Rosen IB, Freeman JL, Ezzat S, Asa SL. RET/PTC-1, -2, and -3 oncogene rearrangements in human thyroid carcinomas: implications for metastatic potential? J Clin Endrocinol Metab. 1996;81:3360-5, https://dx.doi.org/ 10.1210/jcem.81.9.8784097

20. Soares P, Fonseca E, Wynford-Thomas D, Sobrinho-Simoes M. Sporadic RET-rearranged papillary carcinoma of the thyroid: a subset of slow growing, less aggressive thyroid neoplasms? J Pathol. 1998;185:71-8, https://dx.doi.org/10.1002/ (SICI)1096-9896(199805)185:1\%3C71::AID-PATH42\%3 E3.0.CO;2-S

21. Tallini G, Santoro M, Helie M, Carlomagno F, Salvatore G, Chiapetta G, et al. RET/PTC oncogene activation defines a subset of papillary thyroid carcinomas lacking evidence of progression to poorly differentiated or undifferentiated tumor phenotypes. Clin Cancer Res. 1998;4:287-94.

22. Bongarzone I, Fugazzola L, Vigneri P, Mariani L, Mondellini $\mathrm{P}$, Pacini F, et al. Age-related activation of the tyrosine kinase receptor protooncogenes RET and NTRK1 in papillary thyroid carcinoma. J Clin Endocrinol Metab. 1996;81:2006-9, https://dx.doi.org/10.1210/jcem.81.5.8626874

23. Bounacer A, Wicker R, Caillou B, Cailleux AF, Sarasin A, Schlumberger $\mathrm{M}$, et al. High prevalence of activating RET protooncogene rearrangements in thyroid tumors from patients who had received external radiation. Oncogene. 1997;15:1263-73, https://dx.doi.org/10.1038/sj.onc.1200206

24. Rabes HM, Demidchik EP, Sidorow JD, Lengfelder E, Beimfohr C, Hoelzel D, et al. Pattern of radiation-induced RET and 
NTRK1 rearrangements in 191 post-Chernobyl papillary thyroid carcinomas: biological, phenotypic, and clinical implications. Clin Cancer Res. 2000;6:1093-103.

25. Khoo ML, Ezzat S, Freeman JL, Asa SL. Cyclin D1 protein expression predicts metastatic behavior in thyroid papillary microcarcinomas but is not associated with gene amplification. J Clin Endocrinol Metab. 2002;87(4):1810-3, https://dx.doi. org/10.1210/jcem.87.4.8352
26. Kovacs GL, Stelkovics E, Krenacs L, Gonda G, Goth M, Kovacs $\mathrm{L}$, et al. Low level of cyclin D1 protein expression in thyroid microcarcinomas from an autopsy series. Endocrine. 2005 Feb;26(1):41-4, https://dx.doi.org/10.1385/ENDO:26:1:041

27. Khoo ML, Freeman JL, Witterick IJ, Irish JC, Rotstein LE, Gullane PJ, et al. Underexpression of p27/Kip in thyroid papillary microcarcinomas with gross metastatic disease. Arch Otolaryngol Head Neck Surg. 2002;128(3):253-7.

Sažetak

\section{IZRAŽAJNOST CIKLINA D1, RET I p27 \\ U PAPILARNOM MIKROKARCINOMU ŠTITNE ŽLIJEZDE}

\section{A. Barić, V. Marković, D. Eterović, V. Bedekovic, M. Kontić, Lj. Juretic Kuščic, V. Pešutić Pisac i A. Punda}

Cilj istraživanja bio je odrediti utjecaj izražajnosti RET, p27 i ciklina D1 na pojavu metastaza u regionalnim limfnim čvorovima kod papilarnog mikrokarcinoma štitnjače. $U$ analizu su uključeni histološki uzorci 70 bolesnika podvrgnutih operativnom zahvatu zbog papilarnog mikrokarcinoma štitnjače u Kliničkom bolničkom centru Split od 1999. do 2001. godine. Histološki uzorci papilarnog mikrokarcinoma pohranjeni u parafinu i fiksirani formalinom imunohistokemijski su obojani pomoću tri monoklonska protutijela: RET, protein p27 i ciklin D1. Izražajnost je opisana prema intenzitetu i raspodjeli stanične obojenosti, dijeleći tumore na one koji imaju izražajnost (ekspresori) i one koji ne pokazuju izražajnost (ne-ekspresori). Statistička obrada podataka učinjena je pomoću $\chi^{2}$-testa i Fisherova egzaktnog testa, uz razinu statističke značajnosti od $p<0,05$. Nije uočena statistički značajna razlika u učestalosti metastaza u odnosu na izražajnost RET mutacije $\left(\chi^{2}\right.$-test: $p=0,459$; Fisherov egzaktni test: $p=0,672)$. U 25 uzoraka bila je prisutna izražajnost ciklina D1, od kojih su metastaze bile prisutne u 6 slučajeva, a od 45 uzoraka bez izražajnosti ciklina D1 metastaze su bile prisutne u samo 2 uzorka $\left(\chi^{2}\right.$-test: $\mathrm{p}=0,014$; Fisherov egzaktni test: $\mathrm{p}=0,021)$, iz čega proizlazi da ekspresija ciklina D1 nije presudna za razvoj metastaza u limfne čvorove. Nasuprot tome, ekspresija p27 značajno je povezana s metastaziranjem, jer su metastaze bile prisutne u 3 od 45 ispitanika koji su imali povećanu izraažajnost $\mathrm{p} 27$ ( $\chi^{2}$-test: $\mathrm{p}=0,093$; Fisherov egzaktni test: $\left.\mathrm{p}=0,124\right)$. Ovim istraživanjem potvrdili smo važnost evaluacije izražajnosti p27, ciklina D1 i RET kao i vrijednost njihove primjene u procjeni ponašanja mikrokarcinoma.

Ključne riječi: Tireoidni tumor, papilarni; Tireoidni karcinom, anaplastični; Ciklin D1; Inhibitor ciklin-ovisne kinaze p27; RET protein, humani 